\title{
丘陵地谷底水田に接する下部谷壁斜面下端の刈り取り 草原における植物種組成と環境要因との対応
}

\author{
Environmental Factors Affecting Plant Species Composition of the Herbaceous Layer on Lowermost \\ Hillside Slopes in the Satoyama Landscape
}

\author{
山田 晋* 大久保 悟* 北川 淑子* 武内 和彦* \\ Susumu YAMADA Satoru OKUBO Yoshiko KITAGAWA Kazuhiko TAKEUCHI
}

\begin{abstract}
Forest verges to paddy fields on lowermost hillside slopes are considered one of the most important habitats not only for managing forest species but also for semi-natural meadow species and species in wet conditions in the Satoyama landscape. To clarify the floristic composition of the verges in relation to environmental characteristics such as light intensity, surface soil water content, slope, slope direction and soil thickness, we sampled 33 research plots in the Tama Hills, central Japan. The results showed that although geomorphic locations were almost the same, light intensity and surface soil water content varied among plots, and these differences affected species composition. In the compositional groups of TWINSPAN classification, light intensity and surface soil water content were the principal factors that affected plant species composition. Brighter conditions due to mowing management as well as slope direction significantly enhanced the number of both meadow species and species in fields or at roadsides, while wetter conditions due to the location of aquifer and the difference in soil thickness meant a significant increase in the abundance of wetland species.
\end{abstract}

Keywords: Tama Hills, TWINSPAN, habitat type, light intensity, surface soil water content, soil thickness キーワード : 多摩丘陵, TWINSPAN, 生育立地夕イプ, 日射量, 土㙥水分, 土壌の厚さ

\section{1. 背景と目的}

近年, 二次的自然に扔ける生物多様性への関心が国内外で高まっ ている。なかであ, 㺫り取りや火入れにより, 古くから維持され てきた半自然的な草原は, 近年の土地利用の変化, 人為的攪乱の 停止によって大幅に減少している2。 そのため, 現在屯農業活動 に伴う半自然的草原が存在している農耕地の刈り取り地は, 保全 上, 重要な環境の一つとして注目されている ${ }^{10)}$ 。

このような農耕地に抢ける刈り取り地のひとつとして, 丘陵地 の水田之斜面林境界に立地する刈り取り草原が挙げられる。二次 的自然が立地する典型的な環境の一つである丘陵地では, 谷底低 地の水田（以下, 谷底水田）と, 丘陵斜面の二次林の境界部分で ある斜面の下端において, 水田耕作のための日照を確保すること を目的とした刈り取り管理が行われてきた。その結果, 成立した 半自然的な草原環境には, 畑地・路傍, 草原生, 林縁生, 樹林生, 湿地生植物など幅広い植物が生育し, 丘陵地のなかで最も草本層 植物の多様性が高い空間となっていることが, 最近, 明らかになっ ている ${ }^{5)}$ 12)。

これまでも, 水田周辺部における刈り取り草原の重要性は認識 されてきた。とくに中山間地の傾斜地水田では, 大面積で出現す る田面間の畦畔法面が, 草原生の植物を維持する環境として重要 であることが報告され, 刈り取り頻度 ${ }^{3)}$, 基盤整備(6), 11) 之植物種 の多様性の関連が報告されている。しかし, 丘陵地斜面下端の刚 り取り草原が立地する環境は, 水田から樹林に向かう, 明環境か ら暗環境, 湿潤環境から適湿環境への環境移行帯であり ${ }^{8)}$, 単な る刈り取り草原以上の複雑な立地となっている。そのため, この 刈り取り草原の植物相保全を考えた際, 田面間の畦畔法面の知見 を直接当てはめることはできない。一方，この刈り取り草原の立 地は, 丘陵地においては下部谷壁斜面の下端（以下，谷壁斜面端） と定義されるが, 下部谷壁斜面の植生に関する調查は, これまで
屯行われてきた ${ }^{8), 12)}$ 。しかし，刚り取り管理のために高木層を欠 く立地に扔ける調査は少なく, さらに, 幅広い環境傾度と種組成 との関係を精査した事例は，ほとんどみられない。そこで本研究 では, 丘陵地谷壁斜面端に焦点を当て, 植物種組成々環境要因之 の対応を明らかにすることを目的に, 植生および環境条件の調査・ 分析を行った。

\section{2. 研究方法}

\section{(1) 研究地の概要}

多摩丘陵は関東地方の南西部に位置し, 西部は関東山地, 南部 は三浦丘陵に続く丘陵地で, 第四紀更新世前期に堆積した上総層 群を基盤としている（図一 1 )。研究対象地とした東京都町田市 中央部は, 現在む谷底水田と斜面林がセットで残る, 多摩丘陵で は数少ない地域である。ここでは, 上総層群の 1 累層で, 碩, 砂, 泥層の厚層からなる小山田層が分布しており ${ }^{9)}$, 泥層に接する砂 層の下部は帯水層となっている。

また, 調查対象地は, 全体としては南傾斜をむつ小規模な二次 流域で, 谷型・尾根型斜面が複雑に配列する地形となっている。

\section{(2) 研究方法}

本研究で対象とした谷壁斜面端は，水田の所有者によって，慣 習的に刈り取り管理されている（以下，こうした斜面裙部におけ る刈り取り行為を「裾刈り」と呼ぶ)。調査は, 現在も裾刈りが行 われている箇所を対象として行った（2004 年には 7〜8月に 1 回, 加えて, 場所によっては，5月下旬にも裾刚りが行われた)。小流 域の谷壁斜面端の植生の多様さを把握するため，まず，ほぼ等間 隔（約 $30 \mathrm{~m}$ 間隔）に $1 \times 1 \mathrm{~m}$ の調査区を設置し, その間で屯, 群 落の組成が明確に異なる地点を調查対象に加えた。その結果, 調 查区は合計 33 箇所となった（図－1）。水田と谷壁斜面端との間 にはいずれも農業用水路が掘られている。そこで, 水路際の植生

*東京大学大学院農学生命科学研究科 


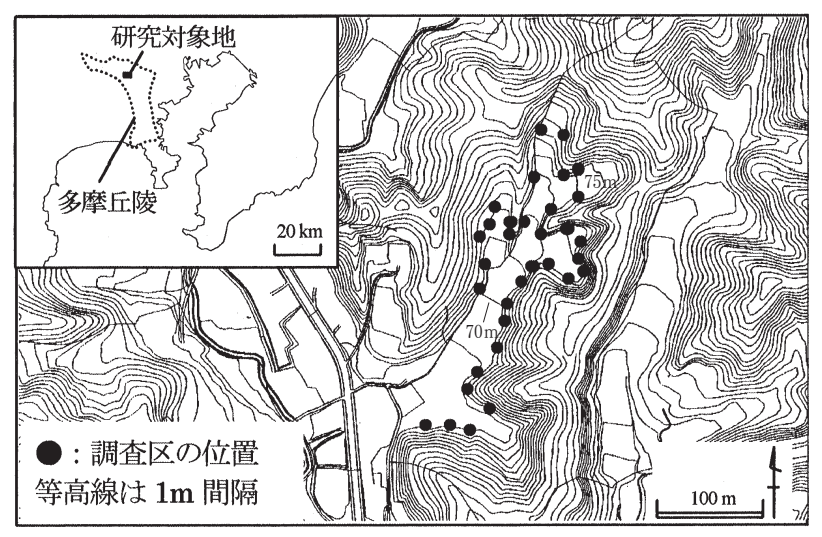

図-1 研究対象地および調査区の位置

の影響を排除するため，水路より $50 \mathrm{~cm}$ 上から調査区を設置した。 各調査区では, 2004 年の春から秋に, 植生調查と環境調査を 行った。植生調查は 2004 年 5 月上旬, 9 月下旬に行い, 調查区 内に出現する全出現種を記録した。環境条件の調査では, 相対日 射量, 土壌表面の体積含水率 (以下, 含水率), 斜面方位, 傾斜 角, 土㙵の厚さを測定した。

相対日射量の測定は, 簡易積算日射量測定システム短期間測定 用（R-2D，大成化工株式会社）を使用した。まず， 7 月下旬の 晴天となった 3 日間にわたり, 累積日射量を測定した。同時に, 小流域に隣接する谷底低地の, 日当たりが良好であると判断され る地点で, 全天光を測定した。各調査区では, 群落高より高い位 置に $2 \mathrm{~cm}$ の長さに切ったフィルムを 3 枚水平に設置した。得ら れた 3 枚のデー夕を平均し, 全天に対する相対值を相対日射量と した。土壤の水分条件としては, 土㙵表面 (地表 $6 \mathrm{~cm}$ ) の体積 含水率を, ADR 法土壌水分計 (DIK-311, 大起理化工業株式会 社）を用いて測定した。測定は, 調査区の中央, 四隅の 5 地点で 行い, 平均值を算出した。 $5,7,9$ 月の 3 回の測定のうち, 晴天 が続いたため各コドラートの違いが最む明確に現れた 7 月のデー 夕を, 解析に用いた。また, 一般に下部谷壁斜面はやや乾性な立 地であるといわれているが ${ }^{15)}$, 丘陵斜面の地表付近に帯水層が分 布する場合には, 土壤表面の含水率は, その影響を受けることが 予想された。そこで, 検土杖を用いて $90 \mathrm{~cm}$ 土䁃断面を作成し, 基盤岩（上総層群）が出現する深さ（以下, 土壌の厚さ）を, 基

盤岩の岩相とともに把握した。

さらに，調査区の上部に接する斜面域において，相観植生夕イ プを記録した。相観植生は，コナラなどが優占する落葉広葉樹林 (以下, 落葉樹林), スギ, 七ノキなどが優占する常緑針葉樹林 (針葉樹林), チガヤ, シバなどが優占する草原（草原）の３タイ プとした。

\section{(3) 解析方法}

植生調査の結果, 合計 219 種が出現した。まず，全出現種を， 日本植生便覧 ${ }^{7}$, 神奈川県植物誌 ${ }^{4)}$ を参考に, 烟地・路傍, 湿地 生, 草原生, 林緑生, 樹林生の 5 つの生育立地に分けた。ただし, 湿地生植物は, 湿った環境を指標する植物という観点から判断し たため, 一般的な水湿植物以外の種も含まれた。

次に, 各生育立地タイプと環境要因の関係を把握するため, 各 調查区に抢ける生育立地夕イプ別出現種数之環境条件之の相関係 数を算出した。さらに, 得られた在・不在の植生デー夕を用いて, TWINSPAN (Two-Way Indicator Species Analysis) ${ }^{1)}$ によ る分類を行い, 第 3 段階までの分割の結果, 得られた 6 つのグルー プ (グループ A〜F) それぞれについても, 生育立地タイプ別の 出現種数, 特徵的な環境条件を比較した。

\section{3. 結果}

\section{（1）立地の環境特性}

調査を行った地点は，概称 $40^{\circ}$ 以上の急傾斜地に立地するた め, 土塨の厚さは, 尾根型の斜面系列に位置する調査区（29調 查区）では $90 \mathrm{~cm}$ 以下と薄くなった。谷頭凹地の下端に位置し, 谷型系列の斜面に位置する調査区（4 調査区）は, 急傾斜地に立 地したものの, $90 \mathrm{~cm}$ 以上の厚い土壌に覆われた。

斜面方位, 裾刈りの状況に応じた相対日射量を, 図一 2 に示す。 相対日射量は, 方位, 裙刈り状況に応じて大きく異なった。裙刈 りが斜面の上部まで行われ，調查区を樹冠が覆わない場合，南向 きの調査区では $50 \%$ 以上の相対日射量となり, 東, 西, 北向き 傾斜の調查区では，30～50\%程度となった。一方，調査区の上部 を樹冠が覆う場合, 相対日射量は南向きで $30 \%$, その他の方位 では $10 \%$ 程度であった。

土壤の厚さと含水率の関係を図- 3 に示す。含水率についても, 10\%の適湿状態から，50\%を超える過湿な状態まで变化に富んだ。 岡 ${ }^{9)}$ が指摘するように, 本調査地では泥層に上接する砂層下部が 帯水層となっていたが，50\%を超える過湿な立地は，帯水層を覆 う土壤が， $20 \mathrm{~cm}$ 程度の薄い場合に限っ

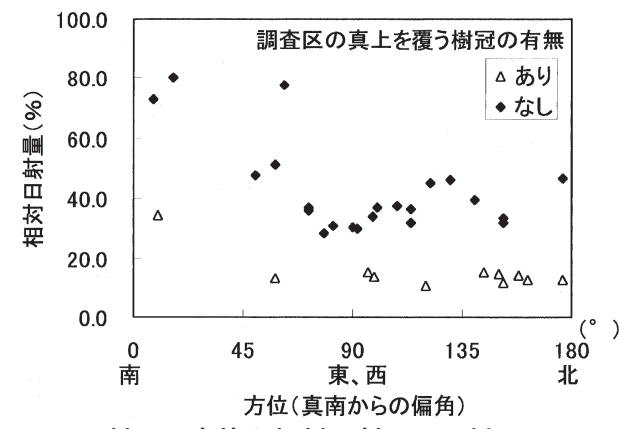

図-2 斜面の方位と相対日射量の関係

表-1 環境条件と生育立地タイプ別出現種数の相関関係

\begin{tabular}{|c|c|c|c|c|c|c|c|c|c|}
\hline & \multicolumn{4}{|c|}{ 環境条件 } & \multicolumn{5}{|c|}{ 生育立地タイプ } \\
\hline & 日射量 & 含水率 & $\begin{array}{c}\text { 土壌の } \\
\text { 厚さ }\end{array}$ & 傾斜 & $\begin{array}{l}\text { 畑地- } \\
\text { 路傍 }\end{array}$ & 湿地生 & 草原生 & 林縁生 & 樹林生 \\
\hline 相対日射量 & 1.00 & 0.22 & -0.03 & $0.43^{*}$ & $0.35 *$ & 0.00 & $0.57^{* *}$ & -0.07 & -0.26 \\
\hline 含水率 & & 1.00 & $-0.39^{*}$ & 0.13 & 0.16 & $0.75^{* *}$ & 0.02 & -0.13 & -0.34 \\
\hline 土袞の厚さ & & & 1.00 & -0.31 & -0.07 & $-0.35^{*}$ & -0.20 & -0.09 & -0.08 \\
\hline 傾斜角 & & & & 1.00 & 0.02 & 0.27 & 0.29 & 0.12 & 0.23 \\
\hline
\end{tabular}

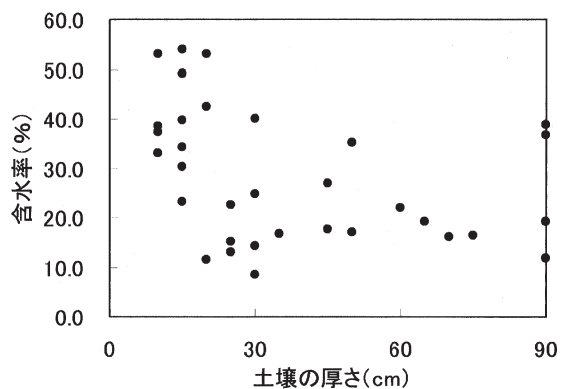

図-3 土鎄の厚さと含水率の関係
てみられた。

また，調査区の上部に接する斜面域 は, 4 箇所を除き, 落葉広葉樹の二次 林あるいは常緑針葉樹の植林であった。 4 箇所の調査区では, 小規模な尾根斜 面の下端にあたるため, 樹林は立地せ ず，上部まで刈り取り草原となった。

\section{(2) 出現種の特徵}

219 種の出現種を生育立地タイプに 分類すると, 畑地・路傍, 湿地生, 草 原生，林縁生，樹林生の順に， 44， 41, 45，44，45 種が記録され，全体としては同程度ずつ 出現した。一方, ひとつの調査区には, 平均 37.8 種 の種数がみられたが，生育立地タイプごとの出現種数 は, 次節のグループ A〜Fにおいて, 大きな違いがあっ たことからもわかると打り，調査区ごとに变化に富ん だ。

（3）出現種と環境要因との対応

各生育立地夕イプの出現種数と環境条件の相関関係 
を表一 1 に示す。環境条件と有意な相関関係が確認できた生育立 地タイプは, 草原生, 畑地・路傍, 湿地生植物の 3 タイプだった。 草原生植物は相対日射量と強い正の相関を示し $(P<0.01)$, 明 るい環境には多くの草原生植物がみられる傾向があった。同様の 傾向は畑地・路傍植物についてもみられたが, 有意水準はやや低 かった $(P<0.05)$ 。湿地生植物の場合は, 含水率と有意な $(P<$ $0.01)$, また土壤の厚さとやや有意な $(P<0.05)$ 負の相関を示 し, 湿潤かつ土壌の薄い立地に多くみられる傾向が確認された。
ただし，土壤の厚さと含水率の間にも，やや有意な相関がみられ $(P<0.05)$, 図-3 に扔いて土袞表面が過湿であると, 土壤が 薄い傾向がみられたことからも, 湿地生植物が土袞の薄い立地を 好むというよりは, 過湿な立地は, 同時に土壌が薄かったと解釈 するほうが妥当であると考えられた。

次に，TWINSPAN により分類された $6 \supset$ づループの特徵 を表一 2 に示し，分類によって特徴的に出現した種の出現傾向を 表一 3 に示す。各グループは, 種レベルのみならず, 生育立地夕 イプ別の出現種数からみても明確な違い がみられ, 同時にその違いと, 含水率, 日射量の間にも対応がみられた。とくに, 表一 1 で確認された傾向，すなわち，明 環境ほど多くの草原生植物が，過湿環境 ほど多くの湿地生植物がみられる傾向は, TWINSPAN のグループレベルにも当て はまった。

過湿な調查区からなるグループ C, F では, 湿地生植物の種数が, 5 生育立地 タイプ中で最む多くなった。より明環境 のグループ F では, 水田脇や水路にみら れるアカバナ, ヒメクグなどが特異的に 生育するが, 林縁生, 樹林生植物は少な かった。シケシダ，ミゾシダなどがみら れ, グループ F に比べて暗環境なグルー プ C は，6つのグループの中で，全ての 生育立地タイプの種数が最も均衡して出現 した。

残り 4 つのグループについては, 光環境 の違いに概ね対応すると思われる出現種の 違いがみられた。より暗い立地のグループ A，Bでは，ホウチャクソウ，オニドコロ を始めとする樹林生, 林縁生植物が草原生 植物の種数を上回った。一方, より明るい 立地であるグループ D, Eでは, リュウノ ウギク, ウッボグサを始めとする草原生植 物の出現種数が, 林縁生, 樹林生植物を上 回った。グループ D では, 草原生植物と 同時に, 林縁生, 樹林生植物む多くみられ た。一方，6つのグループの中で最む明る いグループEでは，それらは少なくなり， 草原生植物, 畑地・路傍植物を主体とする 種組成となった。また, グループ E は, 上部に続く斜面が草原である点で, 他の調 査区と明確に区別された。

\section{4. 考察}

刈り取りのために高木層を欠く下部谷壁 斜面の植生は, 単一の微地形としてまとめ られないほど，変化に富んでいることが知 られている ${ }^{13)}$ 。大久保ら ${ }^{13)}$ は，その理由を 立地環境が多様なためであると推測してい るが, 本研究の結果, 谷壁斜面端は, 日射 量, 土壤水分, 土壌の厚さの点で, 大きな 環境傾度を持つ立地であることを, 実際に 確認することができた。さらに，大きな環 境傾度, とくに光, 土壤水分に対応する種 組成の変化が観察された。すなわち，適湿 な立地の場合, 種組成は, 暗環境から明環 
境に向かい, 樹林生, 林縁生植物主体（グループ A, B）から, 草原生, 樹林生, 林縁生植物主体（グループ D）を経て, 草原 生, 畑地・路傍植物主体 (グループE) へと変化した。また, 過 湿な立地の 2 グループ（グループ C, F）では，いずれむ湿地生 植物が多く確認された。

多くの種をむたらす要因となった，変化に富む光・水分条件が, ごく限られた範囲の小流域に確認された要因としては，まず，斜 面方位, 土袞の厚さに起因する帯水層の相対的な位置といった, 地形や地質の影響が挙げられる。例えば, 光条件は, 丘陵地の特 徵の一つであるさまざまな斜面方位の入り組んだ地形15)に, 大き く影響を受けた。斜面方位の違いが, 光条件などを通して植物の 種組成に影響を与える事例は，国内外で報告されているが年，16)， 本調査でも, 南向き斜面か否かにより, 谷壁斜面端の光条件は大 きく異なった（図一 2)。一方, 谷壁斜面端の水分条件は, 基盤 岩, 土畩の厚さに影響を受けた。すなわち, まず帯水層が地表付 近にあり, さらに土壤が薄い場合に, 土壤表面が過湿になった。 $20 \mathrm{~cm}$ 以下という薄い土壌は, 土壤が薄い下部谷壁斜面 ${ }^{15}$ の中で あ, 特に薄い土壤の立地であり, ごく局所的な斜面の形態, 傾斜 による影響を受けて出現したと考えられる。

次に，とくに光条件は，斜面方位という地形の影響だけでなく， 裾刈り管理によっても大きく影響を受けた。つまり，斜面上部ま での裙刈りが行わなかった場合，相対日射量は $50 \%$ に届かなかっ たが, 草原生, 畑地・路傍植物は, 明るい立地ほど多くの種数が みられることを考えると（表一 1 )，とくにこれらの生育立地夕 イプをもつ種の生育に, 裾刈りが深く関わっていることが推測さ れる。同様のことは, 過湿な立地の中であ明るい環境であるグルー $フ^{\circ} \mathrm{F}$ に特徵的にみられた, 水田の畦畔や水路に生育する湿地生 植物についてもあてはまると考えられる。以上より, あともと適 湿から過湿という大きな水分傾度をむつものの, 林床的あるいは 林縁的な立地であるために，比較的暗い環境であった谷壁斜面端 は, 裾刈りという管理が加わることで初めて, 適湿な明環境, 過 湿な明環境を含む多様な立地として機能し, 草原生, 畑地・路傍 植物, 水田の畦畔や水路に生育する湿地植物という幅広い植物の 生育環境になったと推測できる。すなわち, 大久保ら ${ }^{13)}$ 指摘す ると打り, 谷壁斜面端に打ける多様な草本層植生は, 自然条件之 人間の管理が組み合わさることで初めて発現したと考えられる。

以上のように, 谷壁斜面端の多様な植物種組成は, 地形・地質, 人為管理によってもたらされる, 多様な光・水分条件に大きく影 響を受けた。しかし, 現場の観察では, 谷壁斜面端の相対日射量 が必ずしも高くない場合でも, シバ草原が立地するような明環境 が上部斜面に立地すると, 出現種は, 今回の調査で最む明るい立 地にみられた, 草原生, 畑地・路傍植物を主体とすることがあっ た（グループ Eのうちの 1 調査区が，これにあてはまる）。上部 斜面まで続く草原は, 樹冠が存在しない点で, 日当たりの良さの 指標になっていると考えられるが，同時に，北川ら ${ }^{5)}$ が指摘する ように，土砂の移動を通して谷壁斜面端の種組成に影響を与える 要因になった可能性むある。このように, 今回考慮できなかった 環境条件の存在は，なお存在することが示唆された。

\section{5. まとめと今後の課題}

谷壁斜面端の刈り取り草原は, 環境傾度の大きな立地であった。 その成立植生は, 光, 水条件と対応を示し, 明環境から暗環境, 湿潤環境から適湿環境に及ぶ多様な環境に応じた種組成の変化が 確認された。谷壁斜面端におけるこの大きな環境傾度は, 丘陵地
の複雑な地形に起因する環境条件之, 管理による光環境の改善が 組合わさった結果，現れたものであると考察され，とくに草原生 植物や一部の湿地生植物には裾刈りによる光環境の改善が大きな 影響を及ぼしていることが予想された。しかし，この刈り取り草 原は, 表土の移動が大きい立地であるため, 単に谷壁斜面端のみ の環境条件だけでなく，上部斜面における土壤の移動などむ，谷 壁斜面端の成立植生に影響を及ぼしている可能性がある。今後, 谷壁斜面端の多様な植生を保全するためには，谷壁斜面端の立地 だけでなく，土砂の滑動状況，そこに含まれる埋土種子の把握を 含め, 上部斜面から谷壁斜面端までの調查を行い, 多様性が維持 されているメカニズムをさらに解明する必要があるだろう。

謝辞

調査を進めるにあたり，東京都多摩環境事務所の鐙美知子，小 滝英俊, 内山香の各氏, 町田歴環管理組合の田極公市理事長始奷 組合員諸氏, 地元農家の方々に多大な便宜を図って頂いた。また, 解析にあたっては, 東京大学農学生命科学研究科の加藤和弘助教 授に適切なアドバイスを頂いた。厚く御礼申し上げる。なお，こ の研究は, 科学研究費補助金 (若手研究 B, 研究代表者: 大久保 悟，\#14760014）の研究費を一部使用した。

\section{参考文献}

1) Hill, M.O. (1979): TWINSPAN, a FORTRAN program for arranging multivariate data in an ordered two-way table by classification of the individuals and attributes: Cornell University Press, Ithaca, New York.

2 ）水見山幸夫（1995）：国土利用変化の概要。西川治監修「アトラス日 本列島の環境变化」：朝倉書店, 東京, $1-16$

3 ) 飯山直樹・鎌田磨人・中川恵美子・中越信和（2002）：棚田畦畔の構 造および刈取りの差異が植物群落に及ぼす影響：ランドスケープ研究 65, 579-584

4 ) 神奈川県植物誌調查会編（2001）：神奈川県植物誌 2001 : 神奈川県 立生命の星・地球博物館, 神奈川, 1580pp.

5 ）北川淑子・大久保悟・山田晋・武内和彦（2004）：丘陵地の谷津田に 接する下部谷壁斜面下端の草本植生の種組成と種の豊かさ：ランドス ケープ研究 67, 551-554

6 ）松村俊和（2002）：整備方法の違いが水田畦畔法面植生に与える影響： ランドスケープ研究 $65,595-598$

7 ）宮脇昭・奥田重俊・望月睦夫（1983）：改訂版日本植生便覧：至文堂, 東京, $872 \mathrm{pp}$.

8 ) Nagamatsu, D. and Miura, O. (1997): Soil disturbance regime in relation to micro-landforms and its effects on vegetation structure in a hilly area in Japan: Plant Ecology 133, 191-200.

9 ）岡重文（1991）：関東地方南西部における中・上部更新統の地質：地 質調查所月報 42, 553-653

10）大窪久美子（2002）：日本の半自然草地における生物多様性研究の現 状：日本草地学会誌 48, 268-276

11）大窪久美子・前中久行（1995）：基盤整備が畦畔草地群落に及ぼす影 響と農業生態系での畦畔草地の位置づけ：ランドスケープ研究 58 , 109-112

12) Okubo, S., Kamiyama, A., Kitagawa, Y., Yamada, S. Palijon, A. and Takeuchi, K. (印刷中) : Management and micro-scale landform determine the ground flora of secondary woodlands and their verges in the Tama Hills of Tokyo, Japan: Biodiversity and Conservation.

13）大久保悟・神山麻子・北川淑子・武内和彦（2003）：多摩丘陵におけ るコナラ二次林抢よび林縁の草本層種構成と微地形との対応：ランド スケープ研究 66, 537-542

14) Small, C.J. and McCarthy, B.C. (2003): Spatial and temporal variability of herbaceous vegetation in an eastern deciduous forest. Plant Ecology 164, 37-48.

15）田村俊和（1987）：湿潤温帯丘陵の地形と土壤：ペトロジスト 31 , 135-146

16）養父志乃夫（1988）：カタクリ個体群の形成ならびにその個体群の育 成管理上の指針：造園雑誌 51, 228-236 